Hydrology and Earth System Sciences, 8(3), 314-326 (2004) (C) EGU

\title{
Forestry and the aquatic environment: studies in an Irish context
}

\author{
Paul S. Giller and John O’Halloran \\ Department of Zoology, Ecology and Plant Science and Environment Research Institute, University College Cork, Cork, Ireland. \\ Email for corresponding author: p.giller@ucc.ie
}

\begin{abstract}
Research on the interaction between plantation forestry and aquatic environments is essential to develop environmentally compatible and sustainable management further. Given, in Ireland, the generally low levels of atmospheric pollution, its geology and maritime climate, and the unique fauna and flora due to its island history, such studies are important not only in the regional context, but also internationally, as they provide an opportunity to examine the effect of forestry and forest management practices on aquatic systems per se, without the complications of acidification. Here, some of the major findings of forestry and water research in Ireland have been reviewed and compared with those from the UK and elsewhere. Plantation forests do not exacerbate acidification in the south of Ireland (Munster) as a whole so that the influence of forestry on water chemistry is far less important than in other parts of the country (such as Wicklow and Mayo). The main forestry influence on streams in Munster is more likely through physical factors, but their nature is unclear. In a few catchments some negative effects are evident, but in many others apparently positive forest effects occur. In this context, smaller scale catchment-level effects appear to be more important in explaining the various relationships between plantation forests and stream ecology than larger scale regional factors. The management of riparian zones, particularly in forested catchments, is of major importance for the structure and functioning of aquatic communities and further work is needed on best management practices. It is suggested that it is unreasonable to base forest management on national Forest-Fisheries guidelines since regions vary too much and the signal from local conditions is too strong. The approach for environmentally benign, scientifically sound forestry management has to be at the catchment scale. Trees in the right places may be beneficial ecologically but further work is needed to identify these locations. The introduction of new forest management practices such as adoption of new species mixes and continuous forest cover are at an early stage in Ireland and their influence on aquatic systems is unknown.
\end{abstract}

Keywords: forest-stream interactions, Irish plantation forestry, hydrochemistry, macroinvertebrates, salmonids, forest management

\section{Introduction}

Ireland is part of the temperate deciduous forest biome. Forests were cleared gradually for agriculture and urbanisation, so that by about 1900 , less than $1.5 \%$ of the Irish landscape was forested. Reafforestation began early in the 20th century and has been based almost entirely on exotic coniferous species such as Sitka Spruce (Picea sitchensis (BONG.) Carr.) and Lodgepole Pine (Pinus contorta Dougl.); these species grow well in the mild maritime climate and coniferous plantation forests are thus an increasingly important land-use in Ireland. Plantation forests cover $10 \%$ of the landscape at present, with the planted area projected to reach $17 \%$ by 2010 . This has raised concerns as to the possible effects of such plantations and associated forestry practices on aquatic resources in the country (O'Halloran and Giller, 1993). These concerns arise because of the direct links between catchment land use and aquatic ecosystems (Hynes, 1975; Giller and Malmquist, 1998) and the fact that many Irish river systems rise in or pass through forested catchments.

In the U.K., coniferous forests exacerbate acidification processes in soft-waters draining geologically sensitive areas which receive atmospheric pollutants (Harriman and Morrison, 1982; Ormerod et al., 1991). Interception and scavenging of the pollutants by the forest canopy is considered to be the principal process involved, coupled with the inability of the substrate geology to buffer the acidity. Being on the western seaboard, Ireland receives less atmospheric pollution than most other European countries yet studies undertaken in a national project, AQUAFOR, 
(Allott et al., 1997; Farrell et al., 1997; Giller et al., 1997; Kelly-Quinn et al., 1997) identified increased acidity at some sites associated with poorly-buffered waters whilst elsewhere, particularly in the south of the country, there is little evidence of acidification.

Other forest influences relate to the sources of energy to stream and river systems. Solar radiation supports instream (autochthonous) primary production, but this is generally less than the energy demand of the consumer communities. Most low order streams depend on energy subsidies (imports of allochthonous organic matter from the upstream ecosystem and the surrounding catchment). Adjacent riparian ecosystems produce coarse particulate organic matter (CPOM) in the form of leaves, twigs and wood, etc. (which enter stream systems through direct litter fall or lateral litter blow), fine particulate organic matter (FPOM) which enters the aquatic system through windblow, surface runoff, bank erosion and, along with dissolved organic carbon (DOC), in groundwaters via subsurface drainage or from rainfall through the overhanging canopy (Giller and Malmqvist, 1998). The balance between autochthonous and allochthonous inputs influences the nature of the river and stream ecosystem and is dependant to a large degree on the riparian zone, in terms of the shading afforded by the riparian vegetation, and the quality, quantity and diversity of the organic matter subsidy to the aquatic system which reflects the actual nature of the riparian vegetation (Murphy and Giller, 2000a, b). Energy subsidy from the riparian zone can also be vital for predators, where terrestrial invertebrates, from well-developed riparian canopies, provide a major energy source for stream-dwelling salmonids, especially during summer and autumn (Bridcut and Giller, 1993). The potential annual energetic contribution of terrestrial arthropods to some headwater streams is comparable to the annual production of aquatic macroinvertebrates (Cloe and Garman, 1996) and can contribute up to $50 \%$ of the annual energy intake of salmonids (Hunt, 1975). Terrestrial adult stages of aquatic insect larvae can play a similarly important role in transferring energy to the riparian zone (Jackson and Resh, 1989).

In addition to the energy subsidy, the input of large woody debris (LWD) from riparian plant communities to river channels and its accumulation therein affects hydrological, hydraulic, sedimentological and morphological channel characteristics as well as the biological productivity (and diversity), especially in low order steams (Gurnell et al., 1995). Input to river systems depends on tree height and age, input mechanisms (such as snow avalanches, blowdown, bankside collapses, severe floods) and transport mechanisms (Gurnell et al., 1995). LWD can provide physical structure for debris dams which alter flow resistance within the channel and lead to changes in pool-riffle sequences as well as creating depositional areas related to hydraulic changes in the channel. The overall effect is a significant enhancement of habitat heterogeneity in the stream system. The altered characteristics of stream channels with significant woody debris (especially complex arrays of different sizes) also has the potentially positive effects of increasing retention of allochthonous matter (Speaker et al., 1988; Gregory et al., 1991), and hence invertebrate production. Additionally fish populations may benefit from provision of low-velocity refuges, profitable feeding positions and visually isolated or sheltered cover from competitors and predators, hence positive relationships have been demonstrated between debris and salmonid density or productivity (Bisson et al., 1987; Inoue and Nakano, 1998; Lehane et al., 2002).

Research on forestry-environment interactions is relatively recent in Ireland, with the major studies commencing in the early 1990s. Given the generally low atmospheric pollution levels in Ireland, such studies are important not only in the regional context but also in that they enable the effect of forests and forestry practices on aquatic systems to be examined per se, without the complications of pollutiondriven acidification effects. Here, some of the major findings of work in Ireland have been reviewed, in particular on rivers and streams in the south of the country, and these findings have been compared with research in the UK and elsewhere.

\section{Water quality issues and forestry in Ireland}

Until the early 1970s, water quality issues were of little interest in Ireland when there was a low level of extensive farming and a small industry base around major coastal centres. Greater awareness of pollution arose with increased industrialisation and intensification of agriculture in the mid 1970 s and early 1980s; coupled with this, came the realisation that forestry might also affect water quality. This recognition was largely based on lessons from abroad, as in Wales (Ormerod et al., 1991; see O'Halloran and Giller, 1993), and was largely focused on the potentially exacerbating effects that plantation forests might have on stream acidity. Indeed, Allott et al. (1990) suggested that there was a correlation between percentage forest cover and acidity, aluminium and dissolved organic carbon concentrations in stream waters in Connemara and south Mayo. Based on these earlier studies, together with a study by Bowman $(1986,1991)$ on the impact of acid precipitation on selected lakes of low buffering capacity, the Irish Forest Service introduced 'Forestry Fishery Guidelines, focusing on the interactions between forests, forest operations and 
water quality (Anon, 1992). These guidelines were to set the agenda for a number of research projects on forest and water quality in Ireland. Examples of the relationship between forestry and water quality at different points of the forest cycle provide a convenient structure to review the findings to date and allows gaps in knowledge and areas for future research to be identified.

\section{IDENTIFICATION OF SITES FOR FOREST DEVELOPMENT}

As in most western European countries, forest development was undertaken largely in the marginal upland areas and in areas of less intensive agriculture (Giller et al., 1993). The Irish Forest Service now requires an assessment of all applications for grant-aid in areas designated as being acid sensitive; the designation of sensitivity is based on alkalinity during sampling on a minimum of four occasions between February and May at intervals not greater than four weeks. Where the minimum alkalinity of the runoff water is $<8 \mathrm{mg} \mathrm{CaCo}_{3} \mathrm{l}^{-1}$ no afforestation is permitted. In areas where levels exceed $15 \mathrm{mg} \mathrm{CaCo}_{3} \mathrm{l}^{-1}$, afforestation is permitted and, if the values fall inbetween, full, partial or no afforestation may be allowed. To help refine these regulations and study the interactions between forestry and aquatic ecology, a national study (AQUAFOR) was established in two areas recognised as poorly buffered, west Galway-Mayo and part of the Wicklow Mountains, along with a more widespread, but less sensitive area of Munster (Fig. 1). Acidity in these areas was essentially episodic in character. In Wicklow and Galway-Mayo, atmospheric acid deposition arose primarily from industrial emissions (Farrell et al., 1997). Other sources of stream acidity, such as marine salts and high background levels of organic acids, were of lesser importance (Allott et al., 1997). Acid episodes at a number of Wicklow and Galway-Mayo sites in poorly buffered streams, chiefly on granite and schist, had minimum $\mathrm{pH}$ values below those recommended for salmonid waters. These acid episodes were also most severe and longer lasting in certain afforested catchments, and tended to occur in winter and spring, when salmonids are at a particularly vulnerable stage of their life cycle. In Wicklow, high concentrations of labile monomeric aluminium were recorded in certain forested catchments and sub-catchments

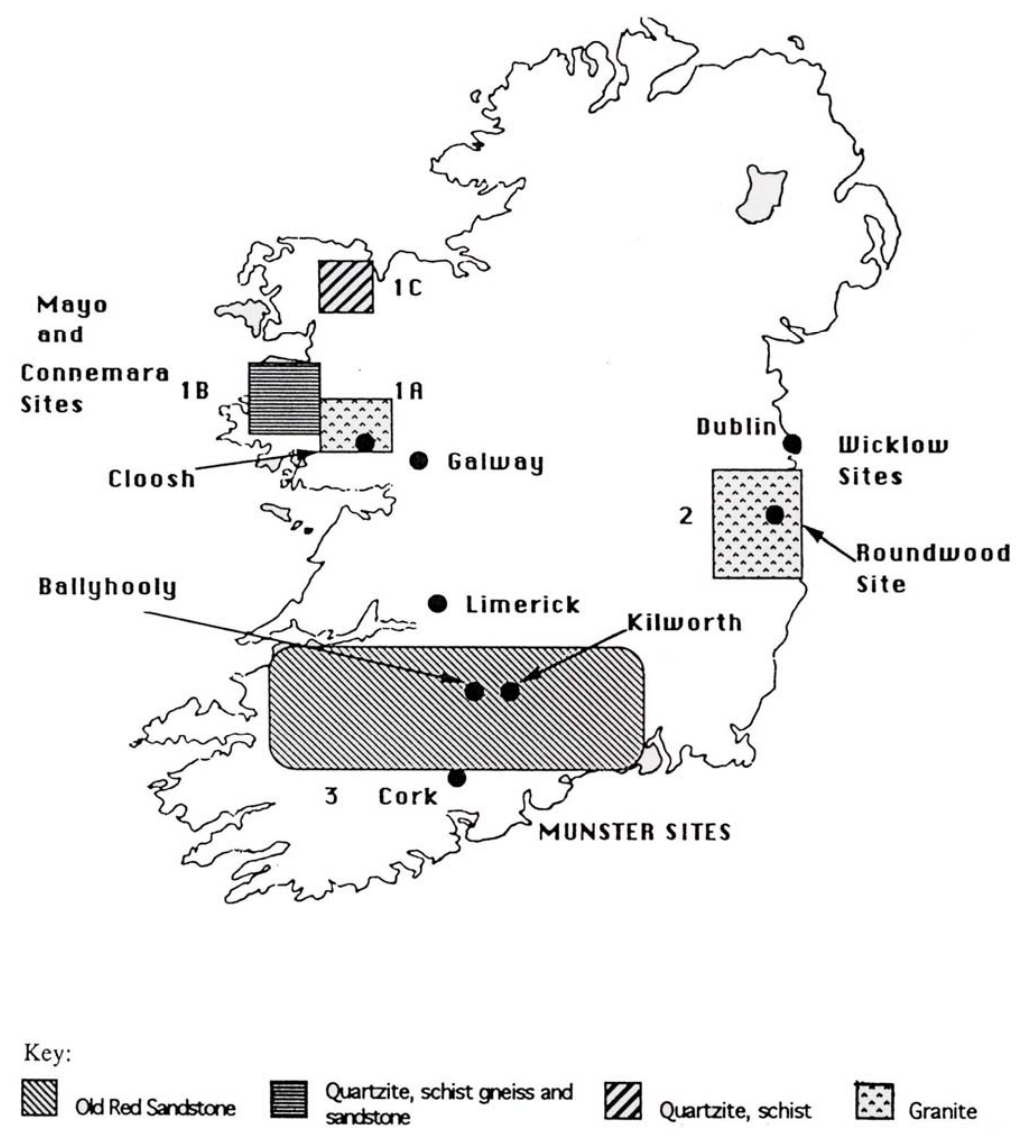

Fig. 1. Location of AQUAFOR study areas and predominant underlying geology (from Giller et al., 1993). 
which were naturally predisposed to acid episodes (values $>40 \mu \mathrm{g} \mathrm{l}^{-1}$ ). A lower diversity of stream macroinvertebrates was also found at these sites. In the Munster region (set largely on Old Red sandstones) to the south, there were no obvious relationships between forest cover and stream acidity (Fig. 2) and the influence of plantation forests on water chemistry is far less important than in other parts of the country (Giller et al., 1997).

Whilst forestry-related hydrochemical changes were evident in the east and west of the country, plantation forests do not lead to acidification and related problems in the south of Ireland. In fact, detailed studies at the catchment level revealed that $\mathrm{pH}$ levels can increase as the stream flows from moorland into a plantation forested area (Fig. 3; Cleneghan et al., 1998a). In one tributary, $\mathrm{pH}$ rose by 1.7 units over a distance of $1.2 \mathrm{~km}$ as the stream entered the forest. Temporal fluctuations in most hydrochemical variables were minor and no acid pulses were noted during spates (Clenaghan et al., 1998a). Whilst extensive surveys across sites, seasons and flow conditions can indicate general patterns, the key to understanding the factors underlying such patterns lies in process studies at the individual catchment scale, in harmony with the EU Water Framework Directive (EC Directive 2000/60/EC).

It is clear from the studies reviewed above that the methods used for designating acid sensitive sites are rather coarse: alkalinity varies across flow conditions and there is a poor relationship between peak acidity and lowest alkalinity values (Kelly-Quinn et al. 1997). One-off sampling may identify acidity which is not serious in the long-term and many forested sites might be designated as sensitive based on alkalinity values, yet ecological data do not support the designation (e.g. Munster area, Giller et al., 1997). The use of the Sodium Dominance Index (after White et al., 1999) is being evaluated as a more reliable method for designating site sensitivity; this, along with production of a revised map of acid-sensitive waters in Ireland, will go a long way to optimising the current forest activities and water quality issues.



Fig. 2. Variation in $\mathrm{pH}$ with season and land use (moorland, agriculture and variable percentage ctachment afforestation) across AQUAFOR study sites in Munster (from Giller et al. 1993).

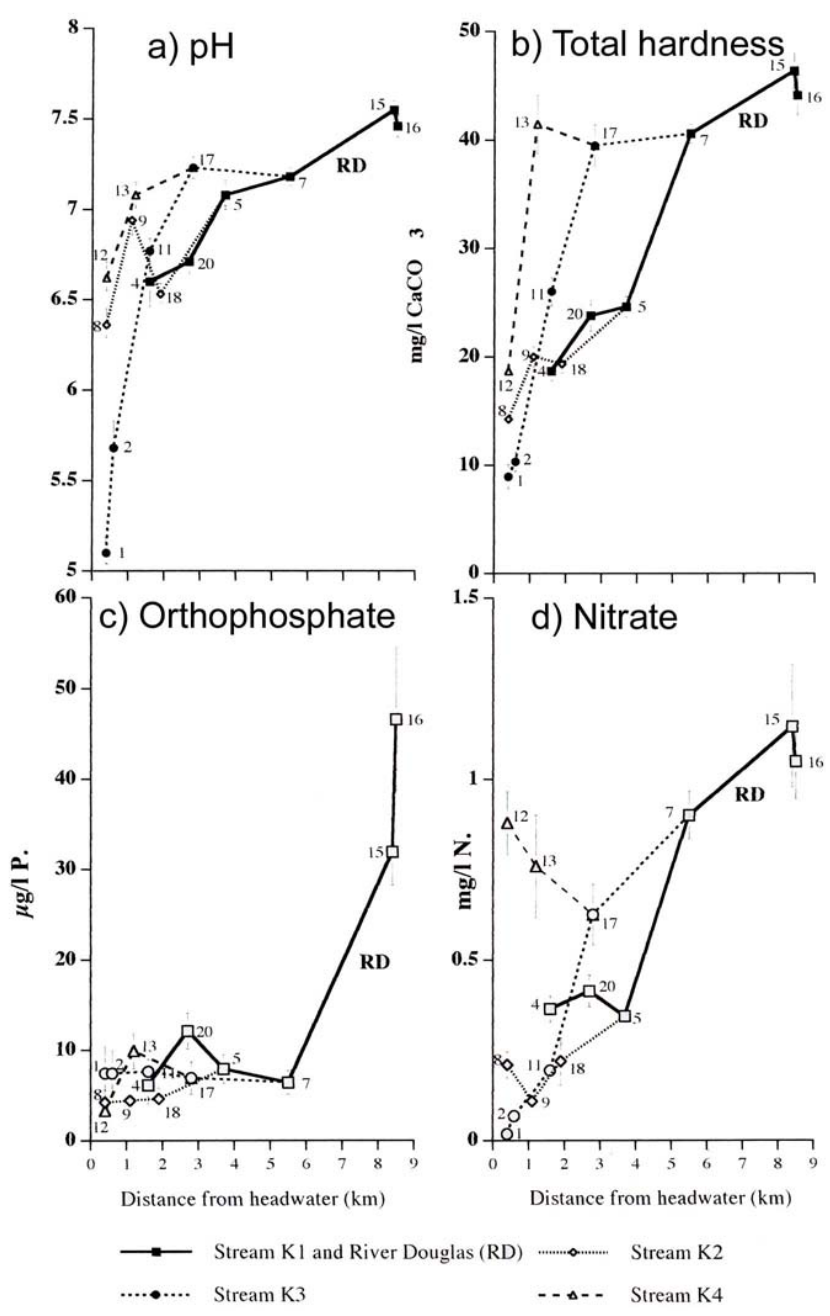

Fig. 3. Longitudinal variation in hydrochemistry in an afforested catchment (Douglas river, Kilworth forest Co. Cork). (After Cleneghan et al., 1998a)

\section{WATER QUALITY DURING AFFORESTATION}

The establishment of a forest results in drastic alterations to the original landscape. Existing vegetation is eliminated and deep drains are dug to remove surface waters from the soil often into nearby streams (O'Halloran et al., 1996). No specific studies on the impacts of afforestation on water quality have been undertaken athough there are limited data available from a re-stock or re-afforestation programme (Duggan. et al., 2001). During the re-afforestation of two sub-catchments felled experimentally (with and without buffer strips, Fig.4), there were no significant hydrochemical or physical habitat changes in either stream following site cultivation. Increases in suspended solids and ortho-phosphate following cultivation and fertilisation were recorded in a tributary draining the adjacent experimental 


\section{Stream one (without a buffer)}

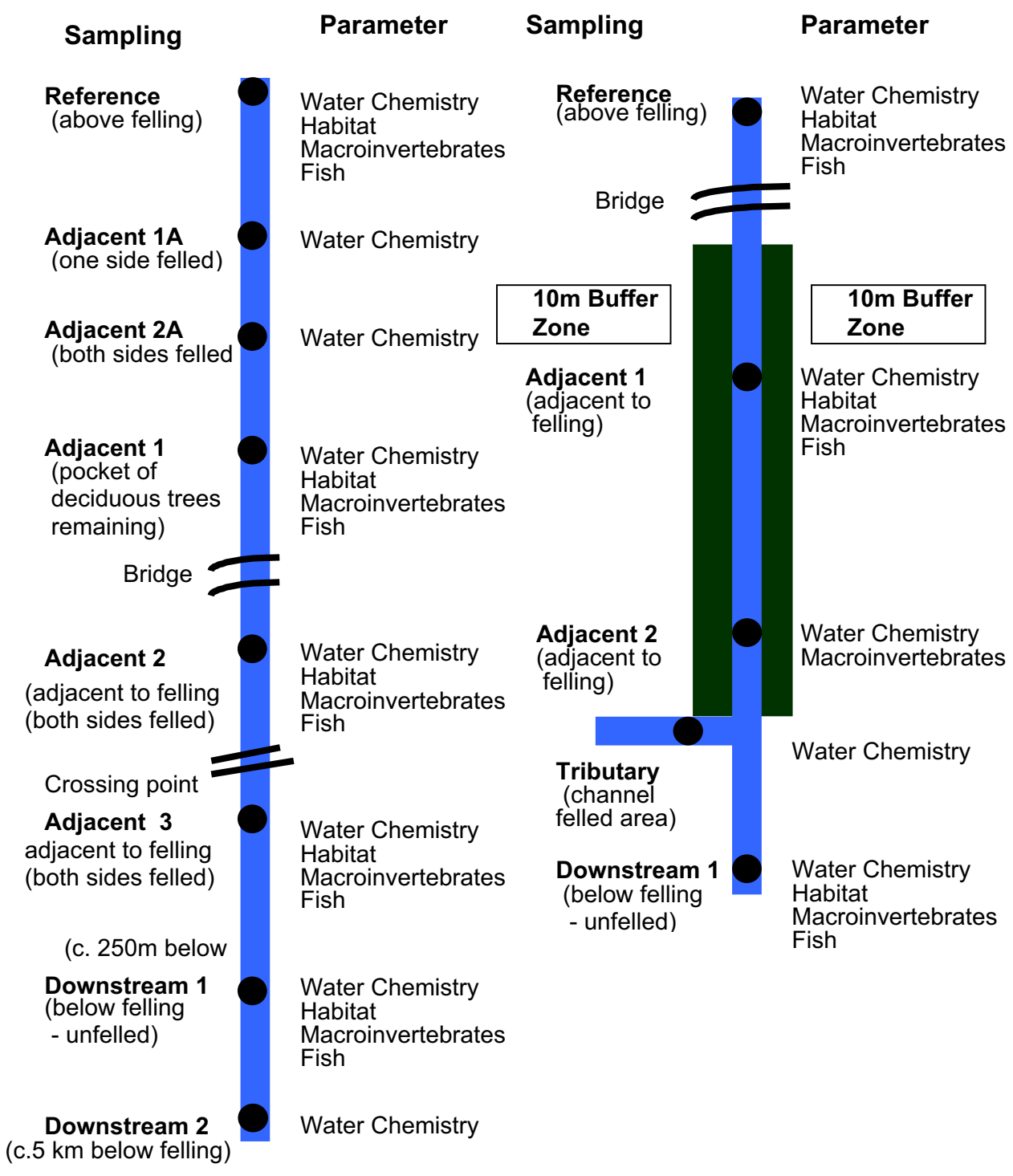

\section{Stream two \\ (with a buffer)}

Parameter

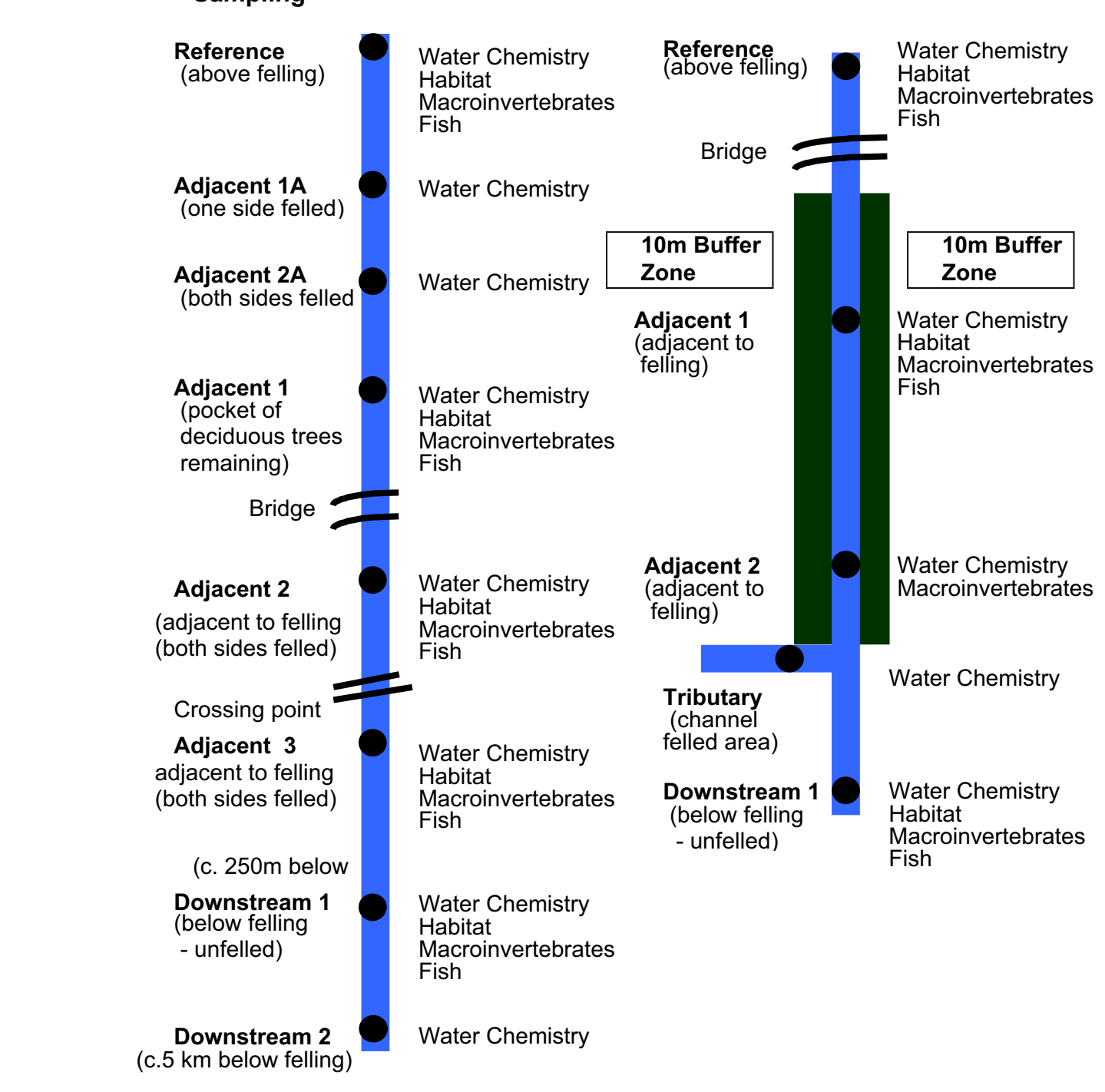

Fig. 4. Experimental design for a clearfelling study with and without buffer strips, at Mallow forest, Co Cork in spring 2000. Sampling stations were located on each stream above, adjacent to and downstream of the experimentally felled sites. A ten metre buffer strip of remnant coniferous vegetation was retained following felling at the adjacent stations on stream two. Hydro-chemistry, in-stream physical habitat, and a range of biological parameters were monitored in each stream before and following site operations

site, but these did not affect the main channel. While the data collected at this single site might indicate what happens during, and for a brief period after re-afforestation under these particular environmental/geological conditions, it is only by examining in detail a range of sites (paired planted and unplanted, on similar catchments) that the true impact can be measured.
This stage is the longest in the forest cycle, varying between 30-40 years duration depending on the tree species. Water quality changes may result from the increased scavenging of ions from the atmosphere by trees, leading to acidification and/or through aerial application of fertilizer or pesticides to the forest. The impact of aerial application of fertilizer has received much less attention than eutrophication of waters by agriculture (Allott et al. 1998). A number of sites along the upper reaches of the River Clydagh in west Cork 
have been sampled during low flow and also during high flow twice a year over 5-6 years following aerial application of fertiliser to newly planted coniferous plantations (Giller et al., 1994). The river was sampled prior to planting and following application of fertiliser at reference, adjacent and downstream stations. There was some evidence of cultural eutrophication in this upland stream as a result of the application of fertilizer (as identified from biotic indices and the macro-algae, Cladophora). In particular, the application of fertilizer in 1994, the last year of the study, had a large effect on the nutrient levels of the river (Giller et al., 1994). The levels of total phosphate and orthophosphate were the highest recorded for the sampling sites and many orders of magnitude greater than all other sampling occasions. Upland eutrophication can thus occur as a result of forest operations. While it is difficult to generalise from a single study site, it is believed that although forest operations do input excess nutrients causing local effects, it is unlikely that the resulting changes are comparable to the extensive damage caused by intensive agriculture.

Pesticides and other organochlorines can enter forested catchments directly or indirectly. The growing canopy can intercept atmospheric pollutants and scavenge these into the river catchment while some pesticides (e.g. lindane) have been traditionally used directly in forest pest management. However, O'Halloran et al. (2003) could detect no differences in the mercury and organochlorine content of dipper eggs Cinclus cinclus, a riverine bird, across rivers, altitudes or land uses. The levels of pollutants found were generally low and represented background levels; hence no influence of forestry was evident. This further emphasises the limited role of atmospheric deposition on forestry-river interactions in the southern regions of Ireland.

\section{WATER QUALITY DURING HARVESTING}

Harvesting of plantations represents a major catchment change that should be expected to influence aquatic systems. The effects of harvesting on water quality are less dependent on geology and influenced more by the size of the felling area, proximity to streams, occurrence of storms and the extent of measures taken during operations to minimise the impact of the clearance. The impacts of harvesting are ranked amongst the top two disturbances influencing stream water quality in many areas of the USA (Resh et al., 1988). In Europe, less attention has been paid to these impacts and Ireland is no exception. The first of its kind in Ireland, an extensive study of clearfelling was established at 16 large forest sites in south-west Ireland. Some preliminary results have been published (Gallagher et al., 2000; Johnson et al.,
2000) and management guidelines produced (Giller, et al., 2002). At each study stream flowing adjacent to or through each clearfell site, a reference station (usually upstream of felling), and stations adjacent to and downstream of the clearfelling operation were established. Longitudinal variation was controlled by sampling all stations prior to felling and seasonal variation was controlled by investigating changes over time at reference stations and ensuring the post felling samples were collected in the same season as pre-felling ones. Sampling was undertaken before felling and several times post felling at each of the sites. Additional spot samples were also taken during high flow events. A range of hydrochemical quantities, including hydrogen ion concentration, total hardness, suspended solids, nitrates and conductivity, were measured using standard methods (Gallagher et al., 2000) .

An index has been developed to measure the impacts of harvesting on hydrochemistry and stream ecology that overcomes the confounding effects of natural variation in space and time. Impacts of clearfelling on physico-chemical parameters over the relatively short time period of this study were not found at all sites and where impacts have been detected, they have mostly been of relatively short duration. The changes post felling are predominantly related to the release of nitrates (Fig. 5), suspended solids, inorganic sediment and soil inputs associated with poor management practices during felling and subsequent operations (Giller et al., 2002).

Nitrate release occurred at sites both with and without buffer strips, and was apparently related to an interaction between area felled, bank slope and input of sediment. It was also found that although buffer strips, some even as narrow as $5 \mathrm{~m}$, could be effective in preventing sediment input, they alone did not preclude the input of sediment, soil and suspended solids into the stream (Johnson et al. 2000). These conclusions point to the catchment-specific nature of the interactions and the lack of generalised patterns.

\section{Influence of forestry on biological systems}

Understanding of the major effects of forestry on aquatic biological communities, based on research in the USA, Scandinavia, Scotland and Wales (Harriman and Morrison, 1982; Bengtsson, 1985; Ormerod et al., 1987b; Gee and Stoner, 1989; MacDonald et al., 1991), has been related largely to acidification and associated aluminium levels (Ormerod et al. 1987a). The AQUAFOR project described earlier was the first to examine the effects of forestry on the ecology of stream and river systems in Ireland in detail and on a large spatial scale. Macroinvertebrate communities and 


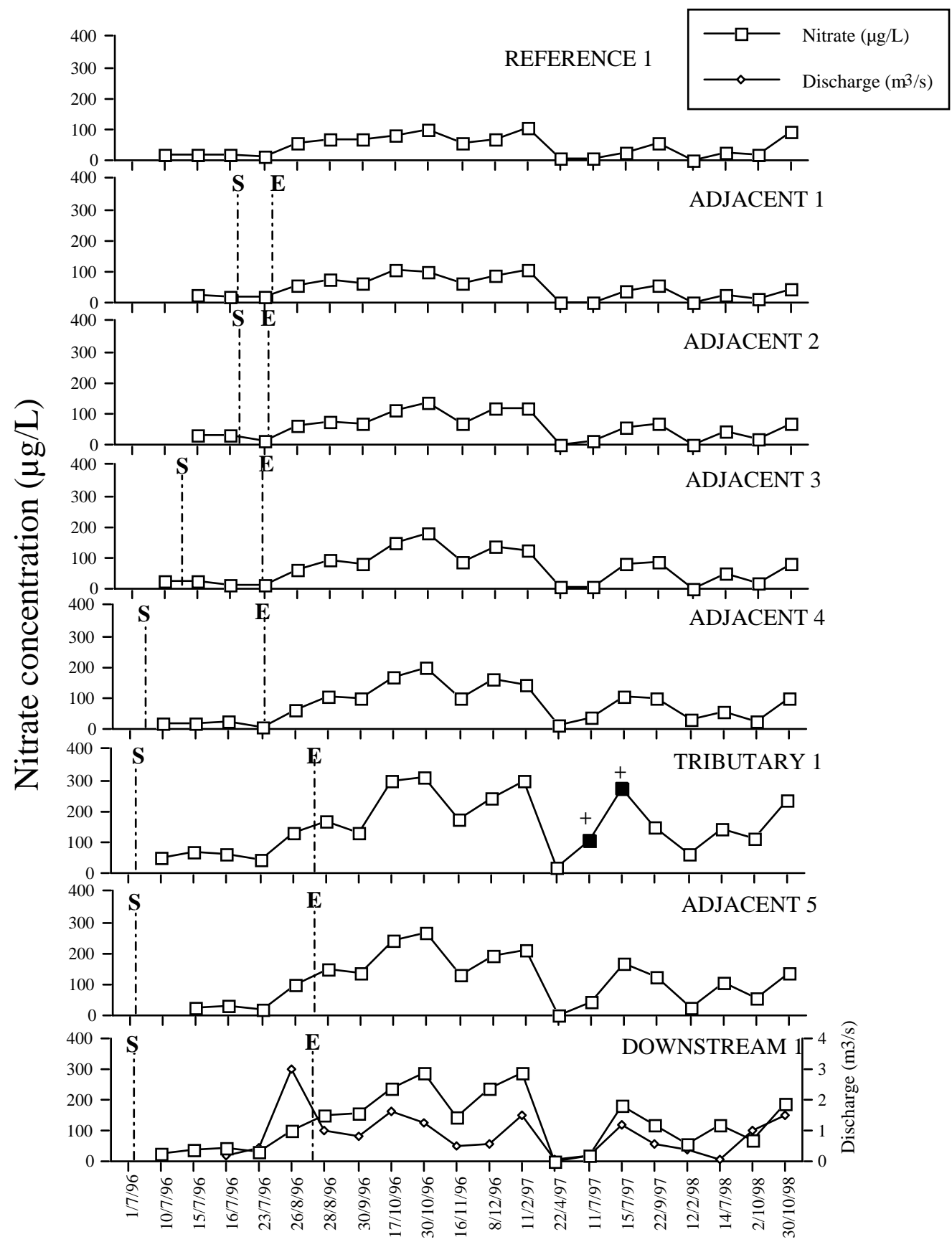

Fig. 5. Variation in stream nitrate in an impacted clearfelled forest stream (Brosna). S and E indicate start and end of clearfelling, respectively. Significant effects are shown by filled squares. (After Gallagher et al., 2000).

salmonid populations were examined, and further extensive work has been conducted more recently on salmonid and Dipper populations, and on the impact of harvesting on invertebrate communities and fish. In addition, intensive studies in a number of specific forested catchments have extended our understanding of the interrelationships between forestry and stream and river communities.
The effects of forestry on macroinvertebrates varies geographically and are related largely to the underlying geology and the forestry influence on water chemistry. In Wicklow, a survey of 50 upland streams showed that those flowing over granite supported less diverse fauna than those flowing over Silurian or Ordovician beds. However, within each geological type, non-afforested streams carried a more diverse fauna than adjacent forested ones (Kelly-Quinn et al., 1997). Nine of the afforested sites supported only the 
most acid-tolerant mayfly species and were devoid of fish (see below).

Similar extensive studies of 45 streams were carried out in the AQUAFOR project in the generally less-sensitive Munster area (Fig. 1). TWINSPAN analysis identified a number of clear clusters of sites based largely on altitude, with percentage afforestation of the catchment playing a secondary role (Fig. 6). Some macroinvertebrate communities from medium altitude $(200-300 \mathrm{~m})$ sites with medium to high levels of forestry $(25->50 \%)$ seem to resemble high altitude ( $>300 \mathrm{~m}$ ) sites more closely than other medium altitude sites with no or low levels of afforestation. These sites also differed somewhat in water chemistry from other sites at similar altitudes and forestry levels. Whilst there appears to be a clear forestry influence on macroinvertebrate communities in the more sensitive geological areas of the east, in general any influence of plantation forests on invertebrates in the Munster area is more likely due to physical factors than to chemical changes.
This is further supported by detailed studies in Kilworth forest (Douglas River). Macroinvertebrate communities in forested sites differed from those above and below the forest but, unlike conifer-afforested systems elsewhere in Europe, they were not impoverished (Cleneghan et al., 1998b). A broad range of environmental factors can be seen as possible influences on the communities (Fig. 7). Salmonid populations also increased from moorland through the forest (Cleneghan 1996; Cleneghan et al., 1998b). These patterns exemplify the primary importance of local ecological factors and the effect that the longitudinal position of forested sites within the river system has on their physico-chemical and biological nature.

Salmonids are quite sensitive to acidification, particularly when accompanied by increases in mono-meric aluminium (Ormerod et al., 1987a). At several of the AQUAFOR sites in Connemara and Wicklow, in areas of sensitive geology and high levels of catchment afforestation, trout populations were absent - these otherwise suitable sites suffered from

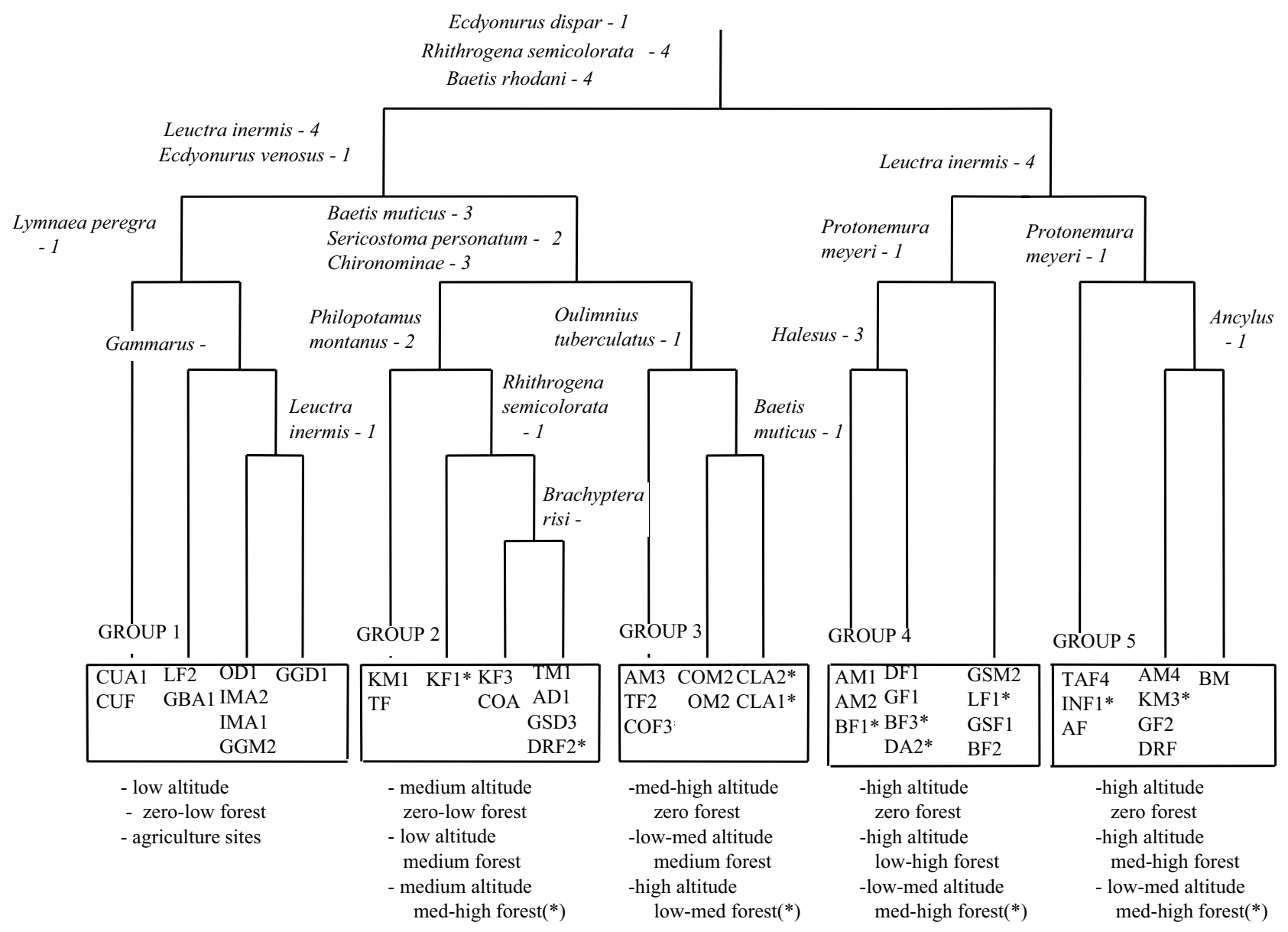

Fig. 6. TWINSPAN classification of spring macroinvertebrate communities from sites varying in land use across the Munster area. Indicator species are shown for each division. Clusters 1-5 are described according to the predominant sites that fall within the cluster. 'Misplaced' sites in relation to other sites of similar afforestation level and altitude are marked with an asterisk, and differ from those other sites in water chemistry. (After Giller et al. 1997). 


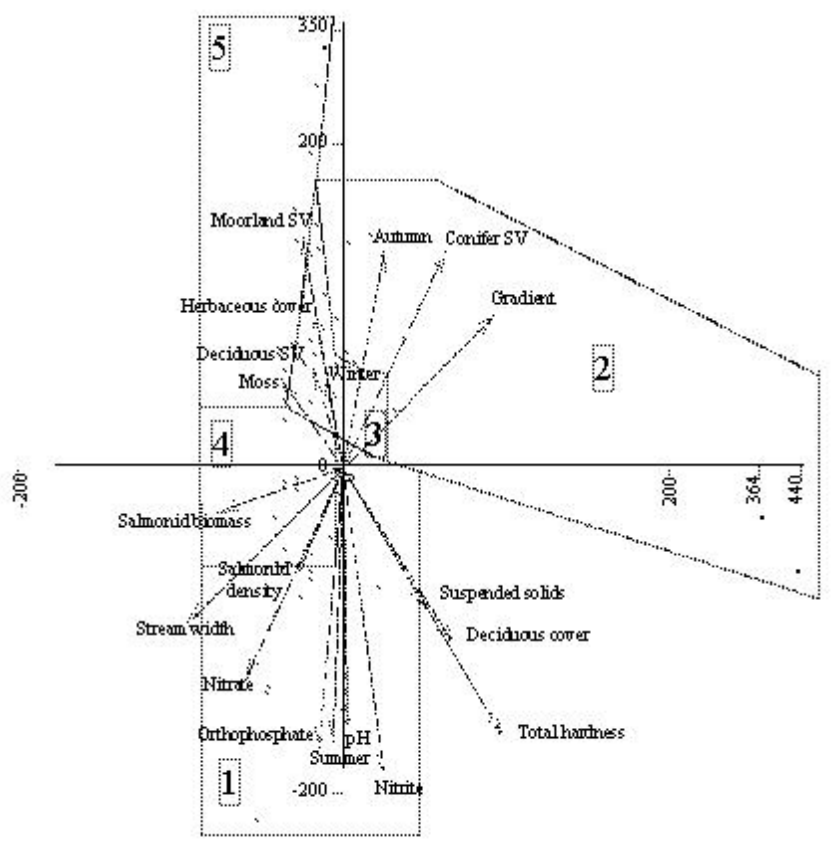

Fig. 7. Canonical Correspondance analysis of macroinvertebrate communities over space and time (season) in the Douglas River catchment, Kilworth Forest. Environmental variables with the greatest influence on variation in sites have the longest biplots (arrows). TWINSPAN clusters (1-5) aresuperimposed on the ordination (cluster 1 - below forest sites; cluster 2 forest sites A; cluster 3 -forest sites B; cluster 4 -forest sites summer; cluster 5 headwater (above forest) sites). (After Cleneghan et al., 1998b). severe and prolonged acid episodes, decreased alkalinity and toxic levels of inorganic aluminium (Kelly-Quinn et al., 1997). In contrast, initial studies in the south of Ireland had suggested that low to medium levels of catchment afforestation may ameliorate the general tendency for salmonid populations to decrease with increasing altitude (Giller et al., 1997). A study of over 120 sites across Munster supported these earlier findings and showed that, whilst the lowest salmonid populations were found in sites of highest forestry cover, this was not always so: overall, no negative effects of afforestation were found on trout (Lehane, 2000; Lehane et al., 2000). Indeed, there was evidence for enhancement of trout populations at certain forestry levels and at certain (low-medium) altitudinal levels (Fig. 8). The major factors explaining variation in trout populations were all habitat- rather than land use-related. This has been shown by intensive studies of salmonid populations in the Douglas catchment in Kilworth forest (e.g. Cleneghan, 1996; Elso and Giller, 2001, Lehane et al., 2002). Very little of the variation in trout populations can be explained by environmental variables on a regional scale but, within catchments, local environmental factors readily explain the variation (Lehane et al., 2000). Smaller-scale catchment level effects appear to be more important in the relationships between land-use and stream and river ecology.

Smiddy et al. (1995) have likewise found no negative impacts of catchment afforestation on Dipper populations

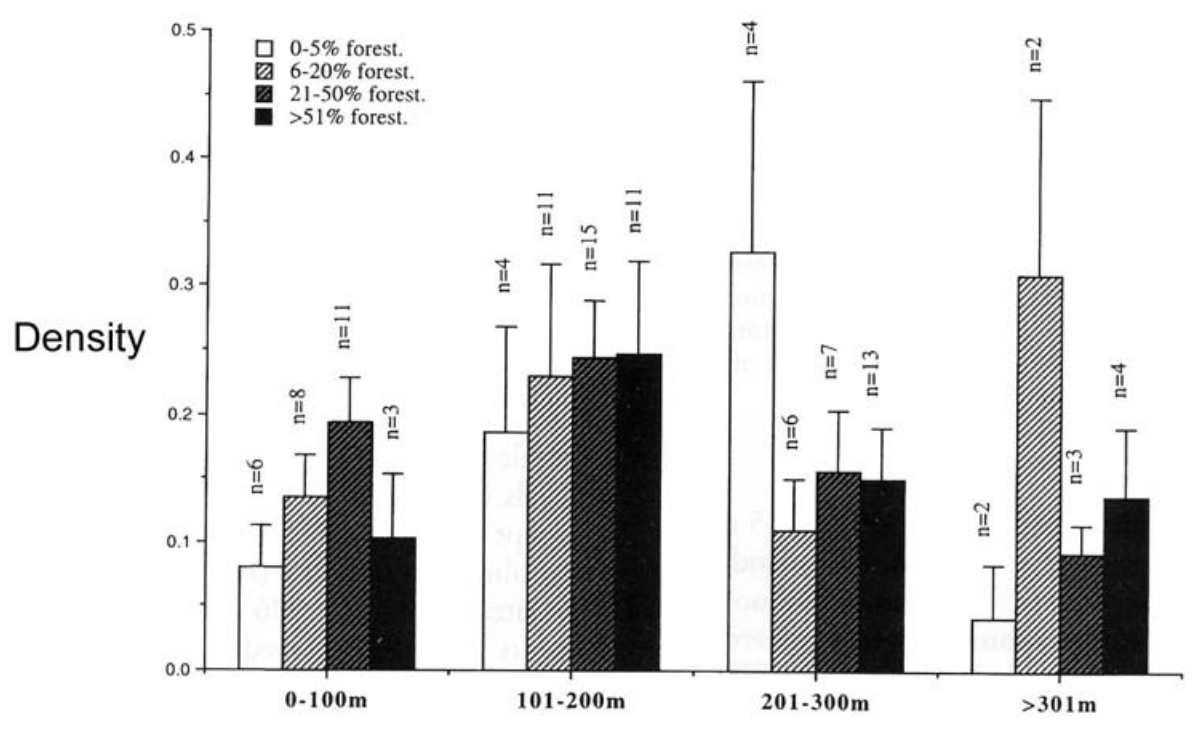

Altitude (m)

Fig. 8. The relationship between brown trout population density (mean $+/-1$ SE), altitude and catchment afforestation in Munster (spring 1996 and 1997 combined). (After Lehane et al., 2000). 
or breeding biology in south west Ireland. This is not surprising, given the lack of major impacts of forestry on surface water acidification in the rivers studied, although there may be some in the more acid sensitive areas of Connemara and Wicklow.

\section{THE EFFECTS OF FORESTRY ON BIOLOGY DURING} THE FOREST CYCLE

The dramatic catchment changes that occur through the forest cycle are expected to affect the aquatic flora and fauna. The experiment described earlier (Fig 4) allowed an assessment to be made of both the short-term impacts on macroinvertebrate communities and salmonid fish populations following reforestation and the longer-term effects after felling at the two streams with and without a protective buffer strip. Longer-term impacts following felling in the stream with no buffer included increased growth of macro-algae, seasonal dominance of a limited number of macroinvertebrate taxa and an increase in density and abundance of $0+$ and $1+$ salmonids where the buffer strip was retained. Few changes relative to the reference station upstream were recorded at adjacent and downstream stations. Following cultivation, preliminary results indicated seasonal changes in macroinvertebrate communities at all stations, and dominance of Orthocladiinae at the downstream station below the tributary. Decreases in brown trout populations were recorded at some reference and treatment stations both one and two years following felling. Monitoring of this kind over longer periods of time are needed to understand how the early stages of afforestation can affect river ecology and how such impacts can be ameliorated.

Low order streams are predominantly heterotrophic and the quantity and quality of energy inputs from riparian vegetation is a key factor in this function. Allochthonous inputs of leaf litter can affect not only the shredder community at any point in the stream, but also, through the decomposition process, the deposit feeders and filterers downstream (Giller and Malmqvist, 1998). Several studies have identified strong seasonal patterns in leaf litter inputs in deciduous woodland streams (e.g. Wallace et al., 1995; Pozo et al., 1997), however, a wide range of different leaf types decompose at different rates and hence provide a dietary continuum extending the supply of allochthonous food beyond the period of maximum leaf fall (Peterson and Cummins, 1974). Monoculture forest plantations may not offer such a continuum and, hence, may influence the ecology of the stream system. Murphy and Giller (2000a) identified such a difference in the pattern of annual variation in allochthonous inputs between a coniferous and deciduous stream system (Fig. 9). Not only did the deciduous system provide a greater amount and diversity of allochthonous material, but the coniferous system suffered from a barren period of supply during the summer. Differences in macroinvertebrate communities and hence ecosystem function (decomposition rates) were also apparent (Murphy and Giller 2000b). The surrounding vegetation is also important in terms of energy subsidy for salmonids via input of terrestrial invertebrates (Bridcut and Giller,1993; see Introduction). The management of riparian zones, particularly in forested catchments is thus of major importance for the structure and functioning of aquatic communities and more work is needed to identify best management practices. The new practices being developed in the UK, such as adoption of new species mixes and continuous forest cover, are at an early stage in Ireland, so that their influence on aquatic systems is unknown at present. Also, given the nature of the forest estate and the soil types available in Ireland, at present there seems to be very little opportunity for intimate forest species mixes, and the use of broadleaves, which are very effective providers of energy subsidies to stream systems, is confined largely to the more visual boundaries of the forest.

Woody debris is a natural component of stream and river systems and is recognised as a major contributor to their physical structure in enhancing habitat, providing shelter and additional resources. Detailed studies have shown the importance of physical habitat on small scale salmonid distributions (Lehane et al., 2001, 2002; Elso and Giller, 2001) and, in particular, the presence and size of pools. Despite the well known ecological importance of LWD, Irish Forestry and Fisheries guidelines recommend clearing such

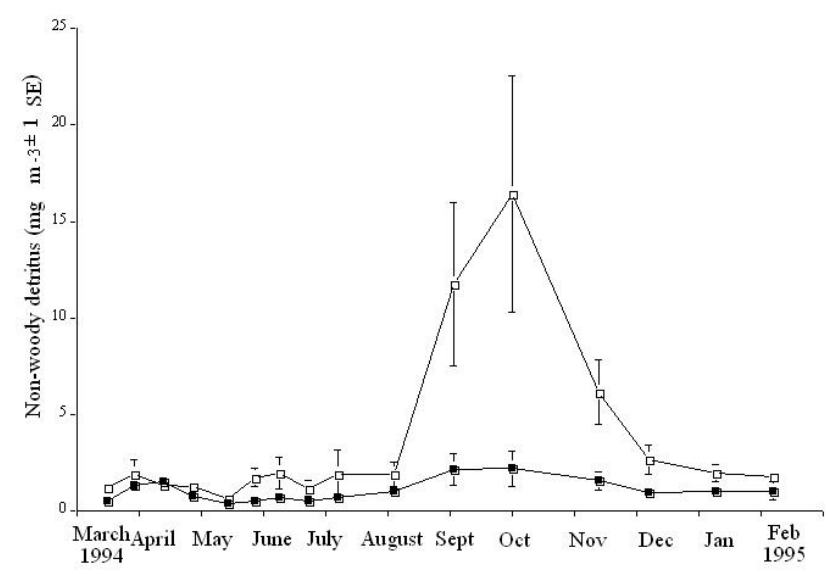

Fig. 9. Seasonal patterns in the mean concentration $\left(\mathrm{mg} \mathrm{m}^{-3}+/-1\right.$ SE) of suspended non-woody coarse particulate matter in streams flowing through a coniferous (filled symbols) and deciduous (open sysmbols) catchment. (After Murphy and Giller, 2000a). 
debris from channels. Experimental enhancement of woody debris through establishment of partial dams (Lehane et al., 2002) showed a considerable enhancement of habitat (more and deeper pools) and an increase in trout density in sections of the stream with debris dams. This kind of positive management could be readily established in low order systems in plantation forests.

\section{EFFECT OF HARVESTING ON STREAM ECOLOGY}

The final phase of the forest cycle, clearfelling or harvesting, represents a particularly dramatic change to the catchment associated with the removal of surrounding vegetation and disturbance to soils. The impact on stream ecosystems is thus considerable (MacDonald et al., 1991). The major study on the effects of clearfelling described earlier (Johnson et al., 2000; Giller et al., 2002) examined not only the impacts on water chemistry but also on the ecology of streams. At eight of the sixteen sites monitored, clearfelling had no effect on macroinvertebrates over the duration of the study. Where impacts were identified, two major patterns emerged, positive and negative. Firstly, the clearfell-associated station became more similar to the reference station. This occurred at adjacent stations where the canopy over the stream had been completely removed and the reference station was largely unshaded. Secondly, at some sites, there were changes in community composition and a decrease in taxon richness (particularly EPT taxa) relative to the reference stations. Such impacts were associated particularly with stations located downstream of machinery crossing points which had been subject to relatively large and long-term inputs of suspended solids, inorganic sediments and soil. The presence or absence of a buffer strip did not appear to influence the responses of macroinvertebrates to clearfelling within the timescales monitored. Negative impacts on salmonid populations (abundance and condition) occurred at those sites that showed changes to macroinvertebrate communities, and were again particularly associated with increased levels of suspended solids and inorganic sediment. More detailed results have been published on one of the study catchments to date (Johnson et al., 2000). Management recommendations to ameliorate the effects of clearfelling on stream and river ecology have also been published (Giller et al.. 2002).

\section{Conclusions}

Increased emphasis on the concept of Sustainable Forest Management (Helsinki Process, 1993; Lisbon Ministerial Conference, 1998) and environmentally sound practices in the forest industry will have significant impact on the day- to-day management practices in forestry operations in Ireland and elsewhere.Concern over the potential impact of Irish plantation forests on the stream environment led to a series of guidelines on management practices based largely on research from abroad. Whilst this may have been appropriate at the time, how effective they are in the Irish context is currently under review. Ireland has not only a unique fauna and flora due to its island history, but also a unique geology and climate, as well as relatively low levels of atmospheric pollution. Objective research on the interaction between plantation forestry and aquatic environments is, therefore, essential to develop environmentally compatible and sustainable management practices.

There is little evidence from the present studies that plantations lead to forest-mediated acidification and related effects in the south of Ireland. Here the influence of forestry on water chemistry is less important than elsewhere in in the country (such as Wicklow and Mayo) where acidicification similar to that found in the UK and Scandinavia also occurs. Streams in the Munster region are more likely to be influenced by physical factors, but their exact nature is not clear. Local conditions govern the ecology of streams in this region: hence, in a few catchments some negative effects are evident, while in others positive effects of forestry occur. It is concluded that it is not reasonable to have Forest-Fisheries guidelines set at a national scale regions vary too much and the signal from local conditions is too strong. The approach for environmentally benign, scientifically sound, forest management has to be at the catchment scale: hence, the integrated catchment management so well utilised in the USA and identified in the Water Framework Directive is necessary.

\section{References}

Allott, N., Mills, W. et al., 1990. Acidification of surface waters in Connemara and South Mayo. Current status and causes. Du Quesne Limited, Dublin, Ireland.

Allott, N., Brennan, M., Cooke, D., Reynolds, J. and Simon, N., 1997. A study of the effects of stream hydrology and water chemistry in forested catchments on fish and macroinvertebrates. AQUAFOR Report 4. Stream chemistry, hydrology and biota, Galway-Mayo region. COFORD, Dublin, Ireland.

Allott, N., Free, G. et al., 1998. Land use and aquatic systems in the republic of Ireland. In: Studies in Irish Limnology, P. Giller (Ed.). Marine Institute, Dublin, Ireland. 1-18.

Anon., 1991. Forestry Operational programme 1989-1993. Government Publications, Dublin, Ireland. 87pp.

Anon., 1992. Forestry fishery Guidelines. Irish Forest Service, Dublin, Ireland.

Bengtsson, G., 1985. Approach and methodology of the health of forests in Sweden. In: Inventorying and monitoring of endangered forest, P. Schmid-Hass (Ed.) . Eidgenossiche Ansalt fur das forstliche Veruchswesen, Birmensdorf. 205-208.

Bisson, P. A. et al., 1987. Large woody debris characterisitcs and function in streams draining old-growth, clear-cut and second- 
growth forests in southwest Washington. Can. J. Fisheries Aquat. Sci., 48, 2499-2508.

Bowman, J., 1986. Precipitation characteristics and chemistry and biology of poorly buffered Irish lakes: a western European baseline for acid rain impact assessment. An Foras Forbartha, Dublin, Ireland.

Bowman, J., 1991. Acid sensitive surface waters in Ireland. Environmental Research Unit, Dublin, Ireland. 321pp.

Bridcut, E.E. and Giller, P.S., 1993. Diet variability and foraging strategies in brown trout (Salmo trutta): an analysis from subpopulations to individuals. Can. J. Fisheries Aquat. Sci., 52, 2543-52.

Cleneghan, C., 1996. The spatial and temporal variation in the freshwater ecology and hydrochemistry of an Irish conifer afforested catchment. PhD thesis, National University of Ireland, University College Cork.

Cleneghan, C., O'Halloran, J., Giller, P.S. and Roche, N., 1998a. Longitudinal and temporal variation in the hydrochemistry of streams in an Irish conifer afforested catchment. Hydrobiologia, 389, 63-71

Cleneghan, C., Giller, P.S. O'Halloran, J. and Hernan, R., 1998b. Stream macroinvertebrate communities in a conifer afforested catchment in Ireland: relationships to physico-chemical and biotic factors. Freshwater Biol., 40, 175-193.

Cloe, W.W. and Garman, G.C., 1996. The energetic importance of terrestrial arthropod inputs to three warm-water streams. Freshwater Biol., 36, 105-14.

Duggan, S.N., O'Halloran, J, Giller, P.S. and Johnson, M.J., 2001. The impact of tree-felling and subsequent restocking on water quality and stream ecosystems. Unpublished report to Enterprise Ireland (HE/1999/343). Dublin, Ireland

Elso, J. and Giller, P.S., 2001. Physical characteristics influencing the utilisation of pools by brown trout in an afforested catchment in Southern Ireland. J. Fish Biol., 58, 201-221.

Farrell, E.P., Boyle, G.M. and Cummins, T., 1997. A study of the effects of stream hydrology and water chemistry in forested catchments on fish and macroinvertebrates. AQUAFOR Report 1. Chemistry of precipitation, throughfall and soil water, Cork, Wicklow and Galway regions. COFORD, Dublin, Ireland.

Gallagher, M., Johnson, M., O'Gorman, K., O'Halloran, J., Giller, P. and Cleneghan, C., 2000. The impact of clearfelling operations on physico-chemical parameters of aquatic ecosystems in southwest Ireland. Verh. Internat. Verein. Limnol., 27, 1108-1115.

Gee, A. and Stoner, J., 1989. A review of the causes and effects of acidification of surface waters in Wales and potential mitigation techniques. Arch. Environ. Contam. Toxicol., 18, 121-130.

Giller, P.S. and Malmqvist, B., 1998. The biology of streams and rivers. Oxford University Press, Oxford, UK.

Giller, P.S., O’Halloran, J. et al., 1993. An integrated study of forested catchments in Ireland. Irish Forestry, 50, 70-88.

Giller, P.S., Cleneghan, C. and O'Halloran, J., 1994. Re-survey of the head waters of the River Clydagh, Coomacheo, Milstreet, Co Cork. Unpublished report to Coillte Teoranta.

Giller, P., O'Halloran, J., Kiely, G. et al., 1997. A study of the effects of stream hydrology and water chemistry in forested catchments on fish and macroinvertebrates. AQUAFOR Report 2. An evaluation of the effects of forestry on surface water quality and ecology in Munster. COFORD, Dublin, Ireland.

Giller, P.S., Johnson, M. and O'Halloran, J., 2002. Managing the impacts of forest clearfelling on stream environments. COFORD, Dublin, Ireland. $51 \mathrm{pp}$.

Gregory, S., Swanson, F., McKee, W. and Cummins, K., 1991. An ecosystem perspective of riparian zones. Bioscience, 41, 540-551.

Gurnell, A., Gregory, S. and Petts, G., 1995. The role of coarse woody debris in forest aquatic habitats: implications for management. Aquat. Conserv. Mar. Freshwater Ecosyst., 5, 143-166.

Harriman, R. and Morrison, B., 1982. Ecology of streams draining forested and non-forested catchments in an area of Central Scotland subject to acid precipitation. Hydrobiologia, 88, 251263.

Hunt, R.L., 1975. Food relations and behaviour of salmonid fishes. In: Coupling of land and water systems, A.D. Hasler (Ed.). Springer, New York, USA. 137-151.

Hynes, H.B., 1975. The stream and its valley. Verh. Internat.Verein. Limnol., 19, 1-15.

Inoue, M. and Nakano, S., 1998. Effects of woody debris on habitat of juvenile masu salmon in northern Japanese streams. Freshwater Biol., 40, 1-16.

Jackson, J.K. and Resh, V.H., 1989. Distribution and abundance of aquatic insects in the forest adjacent to a northern California stream. Environ. Entomol., 18, 278-283.

Johnson, M., O'Gorman, K., Gallagher, M., Cleneghan, C., Giller, P. and O'Halloran, J., 2000. The identification and amelioration of the impacts of clearfelling operations on lotic macroinvertebrates and salmonids in Ireland. Verh. Internat. Verein. Limnol., 27, 1565-1570.

Kelly-Quinn, M., Bracken, J., Tierney, D. and Coyle, S., 1997. A study of the effects of stream hydrology and water chemistry in forested catchments on fish and macroinvertebrates. AQUAFOR Report 3. Stream chemistry, hydrology and biota, Wicklow region. COFORD, Dublin, Ireland.

Lehane, B.M., Giller, P.S., O'Halloran, J. and Walsh, P.M., 2000. Conifer forest location and fish populations in southwest Ireland. Verh. Internat. Verein. Limnol., 27, 1116-1121.

Lehane, B.M., Giller, P.S., O'Halloran, J., Smith, C. and Murphy, J., 2002. Experimental provision of large woody debris in streams as a trout management technique. Aquat. Conserv. Mar. Freshwater Ecosyst., 12, 289-311.

MacDonald, L., Smart, A. and Wissmar, R.C., 1991. Monitoring guidelines to evaluate the effects of forestry activities on streams in the pacific Northwest and Alaska. US EPA, Washington, USA.

Murphy, J.F. and Giller, P.S., 2000a. Detrital inputs to two loworder streams differing in riparian vegetation. Verh. Internat. Verein. Limnol., 27, 1351-1356.

Murphy, J. and Giller, P.S., 2000b. The seasonal dynamics of macroinvertebrate assemblages in the benthos and associated with detritus packs in two low-order streams differing in riparian vegetation. Freshwater Biol., 43, 617-632.

O'Halloran, J. and Giller, P.S., 1993. Forestry and the ecology of streams and rivers: lessons from abroad. Irish Forestry, 50, 3552.

O’Halloran, J., Giller, P.S., Cleneghan, C., Wallace, J. and Koolan, R., 1996. Plantation forestry in river catchments: disturbance and recovery. In: Disturbance and recovery in Ecological Systems, P.S. Giller and A.A. Myers (Eds.). Royal Irish Academy, Dublin, Ireland. 68-82.

O'Halloran, J., Irwin, S., Harrison, S., et al., 2003. Mercury and organochlorine content of Dipper Cinclus cinclus eggs in southwest Ireland: trends during 1990-1999. Environ. Pollut., 123, $85-93$.

Ormerod, S.J., Boole, P., McCahon, C., Wetherly, N., Pascoe, D. and Edwards, R., 1987a. Short term experimental acidification of a welsh stream : comparing the biological efects of hydrogen ions and aluminium. Freshwater Biol., 17, 341-356.

Ormerod, S.J., Mawle, G.W. and Edwards, R.W., 1987b. The influence of afforestation on aquatic fauna. In: Environmental effects of plantation forestry in Wales, J. Good (Ed.). ITE, Monks 
Wood, UK.

Ormerod, S.J., Rutt, G., Weatherley, N. and Wade, K., 1991. Detecting and managing the influence of forestry on river systems in Wales: results from surveys, experiments and models. In: Irish Rivers: Biology and Mangement, M. Steer (Ed.). Royal Irish Academy, Dublin. 163-184.

Peterson, R.C. and Cummins, K.W., 1974. Leaf processing in a woodland stream. Freshwater Biol., 4, 343-368.

Pozo, J., Gonzalez, E., Diez, J., Molinero, J. and Elosegui, A., 1997. Inputs of particulate organic matter to streams with different riparian vegetation. J. N. Amer. Benthol. Soc., 16, 602611.

Resh, V., Boown, A., Covich, A., Gurtz, M.E., Li, H.W., Minshall, G.W., Reice, S.R., Sheldon, A.L., Wallace, J.B. and Wissmar, I., 1988. the role of disturbance in stream ecology. J. N. Amer. Benthol. Soc., 7, 433-455.

Smiddy, P., O'Halloran, J., O'Mahony, B. and Taylor, A., 1995. The breeding biology of the Dipper Cinclus cinclus in south west Ireland. Bird Study 42, 76-81.

Speaker, R., Luchessa, K., Franklin, J. and Gregory, S., 1988. The use of plastic strips to measure leaf retention by riparian vegetation in an Oregan stream. Amer. Midland Naturalist, 12, $22-31$.

Wallace, J.L., 1995. The interaction between forestry and freshwater ecosystems in south west Ireland. Unpublished MSc thesis. National University of Ireland, Cork.

Wallace, J.B., Whiles, M., Eggert, S., Cuffney, T., Lugthart, G. and Chung, K., 1995. Long-term dynamics of coarse particulate organic matter in three Appalachian Mountain streams. $J$. $N$. Amer. Benthol. Soc., 14, 217-232.

White, C.C., Smart, R., Stutter, M. et al., 1999. A novel index of susceptibility of rivers and their catchments to acidification in regions subject to maritime influence. Appl. Geochem., 14, 1093-1099 